\title{
SEJARAH PERKEMBANGAN ISLAM DI BANJARMASIN DAN PERAN KESULTANAN BANJAR (ABAD XV-XIX)
}

\author{
Yusliani Noor*
}

\begin{abstract}
Islamisasi Banjarmasin menghasilkan identitas baru pada etnis Dayak Islam sebagai Melayu sekaligus menjadi Banjar,' dan demikian pula etnis lainnya seperti; Jawa, Melayu, Bugis-Makassar serta Wajo, kbususnya mereka yang berafiliasi, bercampur dan berada dalam suzerinitas Kesultanan Banjar. Suku-suku bangsa ini menghasilkan generasi campuran (mixing generation) karena perkawinan, yang juga menjadi Banjar. Berbagai etnis ini disatukan oleh transformasi dan transkulturasi religiusitas secara genius dari kepercayaan dan budaya Kaharingan-Balian, Hindu-Budha kepada agama Islam dan menjadi berbudaya Islam. Mereka memiliki bahasa Melayu Banjar sebagai LinguaFranca, sekaligus sebagai bahasa pemersatu.
\end{abstract}

Kata Kunci: Islamisasi Banjarmasin, etnis Dayak, dan Melayu Banjar

\section{Pendahuluan}

Kehidupan masyarakat Nusantara sejak runtuhnya suzerinitas kerajaankerajaan Hindu-Budha akhir abad ke-15 mengalami perubahan dalam berbagai

*Dosen tetap FKIP Unlam Banjarmasin.

${ }^{1}$ Kenyataan ini ditandai dengan alur cerita dan kemiripan Naskah-Naskah Hikayat yang dianggap bercorak Melayu, sehingga Hikayat Banjar dan Tutur Candi, memiliki genre yang senada dengan Hikayat Hang Tuah, Hikayat Raja Pasai, Sulalat al-Salatin (Sejarah Melayu), Hikayat Aceh, Cerita Asal Bangsa Jin dan Segala Dewa-Dewa, Salasilab Kutai, yang semuanya menampilkan aspek bahasa Melayu; bahasa sastra, politik dan hukum serta bahasa komunikasi. Lihat Henri Chambert-Loir, 2011, Sultan, Pablawan dan Hakim, KPG (Kepustakaan Populer Gramedia) bekerjasama dengan Ecole francaise d'Extreme-Orient Masyarakat Pernaskahan Nusantara Pusat Pengkajian Islam dan Masyarakat-UIN Jakarta: Jakarta, hlm. 7. Hasil Penelitian antropologis Y. C. Thambun Anyang, menunjukkan bahwa komunitas Dayak Taman di Kalimantan Barat ketika telah Islam menyebut dirinya "turun Melayu" atau 'menjadi Melayu". Lihat Y. C. Thambun Anyang, 1998, Kebudayaan dan Perubahan Daya Taman Kalimantan Dalam Arus Modernisasi, Studi Etnografis Organisasi sosial dan Kekerabatan dengan Pendekatan Antropologi Hukum, Jakarta: Grasendo, hlm. 103. Bandingkan dengan proses diakronis sejak abad ke-15 dalam perspektif Dayak Islam di Banjarmasin yang menjadi Melayu dan juga menyebut dirinya Banjar, sering disebut pula Melayu Banjar. 
aspek. Aspek perubahan terpenting adalah terbukanya ruang (locus) perkembangan agama Islam, yang sejak abad ke-7 telah mulai masuk ke kawasan Nusantara. ${ }^{2}$

Secara formal Islam telah membentuk lembaga politiknya di Samudera Pasai pada abad ke-7 Hijriah (13 M) dengan rajanya bernama Malik As-Saleh, yang wafat pada bulan Ramadhan 698 Hijriah (1297 M). Pada awal abad ke-16 berdiri Kesultanan Demak (1518-1550 M) dengan rajanya yang pertama Raden Patah. $^{4}$

Demak pada awal abad ke-16 telah membentuk kesatuan Ulama juru dakwah, yang disebut 'Wali Sanga. ${ }^{5}$ Kesultanan Demak berjasa terhadap Kesultanan Banjarmasin, bukan semata-mata dari aspek bantuan militer, namun juga dari aspek pelembagaan Islam.

Pelembagaan yang paling penting adalah terbentuknya struktur Kesultanan, sehingga perkembangan Islam menyebar ke seluruh penjuru Kesultanan Banjarmasin. ${ }^{6}$ Hikayat Banjar menyebutkan pasukan Demak yang datang ke Banjarmasin berjumlah 1000 orang pasukan. ${ }^{7}$

Secara sepintas, Islamisasi Banjarmasin ${ }^{8}$ sepenuhnya hasil dari campur tangan Kesultanan Demak, sehingga pemahaman penyebaran Islam di

${ }^{2}$ Abad ke-7 dan 8 Selat Malaka sudah mulai dilalui oleh pedagang-pedagang Muslim. Lihat A. Kardiyat Wiraharyanto, 2008, Sejarah Indonesia Madya Abad XVI-XIX, Yogyakarta:Universitas Sanata Dharma, hlm. 9. Dijelaskan pula bahwa para pedagang Arab menyebut Sriwijaya dengan Sribuza. Bukti lainnya, temuan makam Fatimah Binti Maimun di Leran, Jawa Timur berangka tahun 1082. Juga berita Marcopolo bahwa 1292 di Perlak Aceh telah ada orang-orang beragama Islam.

${ }^{3}$ Hasan Muarif Ambary, 1996, Dinamika Sejarah dan Sosialisasi Islam di Asia Tenggara Abad 11M-17M, dalam Kongres Nasional Sejarah 1996 sub tema Studi Komparatif dan Dinamika Regional, 1996, Jakarta: Departemen Pendidikan dan Kebudayaan RI, hlm. 20. Lihat A. Hasjmy, Adakah Kerajaan Islam Perlak Negara Islam Pertama di Asia Tenggara, dalam A. Hasjmy, 1981, Sejarab Masuk dan Berkembangnya Islam di Indonesia, Kumpulan Prasaran Pada Seminar di Aceh), PT. AlMa'arif, hlm. 204. Lihat juga, Marwati Djoned Poesponegoro, Nugroho Notosusanto, 1984, Sejarah Nasional Indonesia Jilid III, Jakarta: PN. Balai Pustaka, hlm. 17.

${ }^{4}$ Ibid, hlm. 20.

${ }^{5}$ Sartono Kartodirdjo, 1987. Pengantar Sejarah Indonesia Baru: 1500-1900, Dari Emporium Sampai Imperium, Jilid I, Jakarta: Penerbit PT Gramedia, hlm. 23-24.

${ }^{6} \mathrm{M}$. Idwar Saleh,1962, Sedjarah Bandjarmasin, Bandung; Balai Pendidikan Guru, hlm. 81.

${ }^{7}$ J.J. Ras, Hikayat Banjar, The Malay Mythe of Origin, Martinus Nijhoff, hlm. 322-323

${ }^{8}$ Pemakaian terminologi Banjarmasin, berdasarkan penelusuran istilah yang lazim dipergunakan sejak sebelum abad ke-16. Istilah Mo-Ho-Sin, dalam berita I-tsing abad ke-7, ditafsirkan oleh Junjiro Takasusu, sebagai sebutan untuk Banjarmasin. Lihat Slamet Muljana, 2006, Sriwijaya, Yogyakarta: LKis, hlm. 71. Dalam penjelasannya, Junjiro Takasusu menyebut 
Banjarmasin diartikan sebagai bentuk ekspansi dan kekerasan. Apalagi buktibukti peninggalan Hindu-Budha, seperti Candi Agung dan Candi Laras, hanya meninggalkan sisa-sisa reruntuhan bangunan, yang hancur seakan-akan akibat penyerbuan pasukan Demak. Padahal, Hikayat Banjar juga menyebutkan, bahwa Kesultanan Demak sendiri mengutus seorang Khatib ke Banjarmasin, yang bernama Khatib Dayyan. Gelar atau nama Khatib Dayyan lebih mencerminkan nama seorang penyampai khotbah atau penyiar agama daripada nama atau seorang panglima perang. ${ }^{\text {? }}$

Anggapan adanya ekspansi dan kekerasan dalam Islamisasi Banjarmasin, meniadakan peran saluran-saluran Islamisasi Nusantara yang justru lebih penting dan dominan dalam menggambarkan kedatangan, penerimaan dan penyebaran Islam di Banjarmasin.

Teori-teori tentang saluran Islamisasi Nusantara yang banyak dibahas oleh para orientalis seperti; van Leur, B.O. Scherieke, Pijnappel, J.P. Maquette, C. Snouck Horgronje, Crewfurd, Keyzer, Norduyn, Niemann dan Hollander, van Brueinessen, hingga Karel Steenbrink. Sementara dari kalangan Muslim, antara lain; Syed Muhammad Naquib Al-Atthas, Fatimi, HAMKA, P.A. Hoesein Djajadiningrat, Azyumardi Azra dan Uka Tjandrasasmita. Mereka mengkaji Islamisasi Nusantara melalui saluran-saluran: perdagangan, perkawinan, birokrasi pemerintahan, tasawuf dan tarekat, pendidikan serta kesenian. ${ }^{10}$

Saluran-saluran Islamisasi yang berorientasi sungai sesuai dengan ekologis Banjarmasin. Ekologi komunitas Banjarmasin adalah sungai. Sungai

Mo-Ho-sin sebagai Banjarmasin berdasarkan pada kesamaan pengucapan. Dalam berbagai peta kuno, yang dibuat orang-orang Eropa, sebutan untuk wilayah Kalimantan bagian Selatan, Tenggara,Tengah serta Timur adalah Banjarmasin. Dalam Fig. 74, peta yang dibuat Willem Lodewijcksz tahun 1598 disebutnya "Bandermacsin”. Dalam peta yang dibuat oleh Theodor de Bry tahun 1602, Fig. 102, dengan sebutan "Bandermach". Selanjutnya, Antonio Sanches membuat peta dalam tahun 1641 dengan menyebut "Bandermasyn", dan peta yang dibuat oleh Jan Jansson tahun 1657, menyebut dengan tulisan "Banjermshin". Lihat Thomas Suarez, 1999, Early Mapping of Souteast Asia "The Epic Story of Seafarers, Adventurers, and Cartographers, Who First Mapped The Regions between China and India", Singapore-Hongkong-Indonesia: Periplus Editions. hlm. 180. Berdasarkan peta kuno itu, maka sebutan Banjarmasin adalah sebutan yang diberikan untuk seluruh kawasan geografis Kalimantan Selatan, Tenggara, Tengah dan sebagian Timur, sejak abad ke-15.

${ }^{9}$ MZ. Arifin Anis. 2000. Banjarmasih Sebagai Bandar Perdagangan Pada Abad XVII. Vidya Karya, Jurnal Pendidikan dan Kebudayaan FKIP UNLAM. Banjarmasin. Tahun XVIII, No.2 , Oktober 2000. hlm. 92.

${ }^{10}$ Marwati Djonet Poesponegoro, Nugruho Notosusanto, Op.cit. hlm. 180 
merupakan panggung pertemuan berbagai kelompok masyarakat, dan pada akhirnya membentuk suatu komunitas dengan diwarnai berbagai macam budaya. ${ }^{11}$

Pewarnaan bermacam budaya pada gilirannya terbentuk dalam format yang bercorak Banjar, dengan sentuhan Islam. ${ }^{12}$ Meskipun Islam telah masuk dalam lembaga politik dan memiliki legitimasi formal di Kesultanan Banjarmasin sejak perempatan awal abad ke-16, sebagai agama resmi istana, namun penyebaran dan perkembangannya melalui proses waktu dan berlangsung secara kontinyu. Apalagi menurut Azyumardi Azra, bahwa proses Islamisasi pada etnis Dayak dari abad ke- 16 hingga pertengahan abad ke-18 berjalan sangat lambat. ${ }^{13}$ Disinilah pertautan jalur bawah 'Bottom Up' dengan jalur atas 'Top Down', memerlukan penjelasan yang seimbang, agar penilaian terhadap perkembangan Islam di Banjarmasin, yang terlembaga melalui Kesultanan Banjarmasin tidak digeneralisir sebagai sebuah rekayasa kultural, apalagi rekayasa politik, yang sangat dipaksakan. ${ }^{14}$ Karena itu, peran sejarah yang menggambarkan Islamisasi secara natural dengan 'bil bikmah wa bil mau'ijatil hasanah' (dengan cara-cara mengharapkan hikmah petunjuk Allah swt., dan dengan cara-cara yang baik), akan menampakkan wajah Islam yang 'Rabmatan lil-alamin' di Kesultanan Banjarmasin.

Kesultanan Banjarmasin dan Islamisasi Banjarmasin menghasilkan identitas dan kultur baru yakni identitas dan kultur Banjar, dengan karakteristik bercorak Islam dalam berbagai bentuknya. Pembentukan identitas dan kultur baru memerlukan suatu kecerdasan lokal (Local Genius) yang tentunya dimiliki masyarakat Banjar. Kecerdasan lokal (Local Genius) menampak pada berbagai

${ }^{11}$ Herry Porda Nugroho Putro. 2009. Sungai di Kalimantan Selatan Dalam Perspektif Sejarah. Makalah pada Seminar Nasional Pendidikan "Kemaritiman Dalam Perspektif Historis dan Pendidikan”. FKIP Unlam. Banjarmasin. 10 November 2009. hlm. 10.

${ }^{12}$ Menurut Alfani Daud, Islam merjadi bingkai dari Kebudayaan Banjar. Lihat Alfani Daud, 1997. Islam dan Masyarakat Banjar: Deskripsi dan Analisis Kebudayaan Banjar. Jakarta:Penerbit PT. RajaGrafindo Persada. hlm. 541.

${ }^{13}$ Azyumardi Azra,Islam Nusantara, Jaringan Global dan Lokal, Bandung: Mizan,. hlm. 251

${ }^{14}$ Islamisasi Banjarmasin selalu dikaitkan dengan superior Banjar terhadap Dayak. Padahal terbentuknya Urang Banjar tidak bisa dilepaskan dari suku Dayak, yang merupakan salah satu asal etnis yang paling dominan di Banjarmasin. Lihat Tutung Nurdiyana, 2010. Superioritas Banjar Dalam Empat Mitos bubungan Banjar dan Dayak. (Mitos Kosmogini Datu Adam dan Datu Tihawa, Legenda Raksasa dari Langit, Matundang Kaling dan Legenda Kerajaan Kayu Tangi). Banjarmasin. hlm. 1. Lihat juga, Marko Mahin, 2004. Urang Banjar: Identitas dan Etnisitas di Kalimantan Selatan, Jurnal Kebudayaan Kandil, Edisi 6, Tahun II, Agustus-Oktober, Lembaga kajian Ke-Islaman dan Kemasyarakatan, Banjarmasin. 
wujud kebudayaan Banjar. Oleh sebab itu, pemahaman yang sangat penting tentang Islamisasi Banjarmasin abad ke-15 hingga abad ke-19 dengan segala aktivitas manusia dan komunitasnya, akan memberikan gambaran pola jaringan sosial (social network), yang telah membentuk sebuah masyarakat Islam dalam sebuah negara bangsa Kesultanan Banjar, sebagai potret dari realitas eksistensi Urang Banjar.

\section{Jaringan Sosial (Social Network) dan Saluran-Saluran Islamisasi Banjarmasin dari Abad Ke-15 Hingga Abad Ke-19: Perkembangan Islam dan Peran Kesultanan Banjar}

Jaringan sosial menurut Bambang Rudito dan Melia Famiola adalah sekumpulan dari hubungan. Hubungan tersebut mulai dari yang paling sederhana hingga memiliki banyak hubungan (multiple relationship). Bentuk hubungan tersebut bukan hanya sekedar pertukaran atribut atau sesuatu hal pada suatu tempat atau suatu waktu, tetapi dapat juga berupa aliran (flow) antara individu atau sekumpulan obyek (node). ${ }^{15}$

Kedushin, menyatakan bahwa dalam ilmu sosial ada tiga jenis jaringan; pertama, ego-centric, yakni sebuah jaringan yang berhubungan dengan perseorangan. Kedua, social-centric, yang digambarkan oleh Russell Bernard's sebagai sebuah kotak yang isinya berbagai bentuk jaringan. Ketiga, social-centric open system, yakni jaringan sosial sistem terbuka, seperti jaringan antar elite, jaringan antar pedagang dan jaringan antar ulama. ${ }^{16}$ Pola Jaringan sosial menurut Ruddy Agusyanto setidak-tidaknya mengandung tiga hal; pertama, jaringan sosial karena kepentingan (interest). Kedua, jaringan sosial karena emosional (sentiment) dan ketiga, jaringan sosial karena power. ${ }^{17}$

Saluran Perdagangan, Jaringan Sosial Pedagang Muslim di Banjarmasin. ${ }^{18}$ Hasil penelitian Meilink-Roelofsz menjelaskan aktivitas perdagangan dalam kurun niaga sejak sebelum abad ke-15, sudah bersifat besar-besaran, artinya sudah ada bulk trade, karena adanya perdagangan beras

\footnotetext{
${ }^{15}$ Bambang Rudito. Melia Famiola. 2008. Social Mapping Metode Pemetaan Sosial Tebnik Memahami Suatu Masyarakat atau Komuniti. Penerbit Rekayasa Sains. Bandung. hlm. 147.

${ }^{16}$ Kedushin dalam Bambang Rudito. Melia Famiola. Ibid. Lihat juga Charles Kedushin. 2004. Introduction to Social Network Theory. Basic Network Concepts. hlm. 1-3.

${ }^{17}$ Ruddy Agusyanto. 2009. Jaringan Sosial Dalam Organisasi. Jakarta: Penerbit Rajawali Pers. hlm. 34-35.

${ }^{18}$ Tesis Weber selalu menempatkan saluran perdagangan sebagai faktor menentukan Islamisasi Nusantara. Lihat Taufik Abdullah et.al, Tesis Weber dan Islam di Indonesia, dalam Agama, Etos Kerja dan Perkembangan Ekonomi, Jakarta: LP3ES, hlm. 28.
} 
dan lada yang memerlukan kapal dengan muatan besar. ${ }^{19}$ Hasil penelitian Manguin, yang berlandaskan sumber-sumber China, bahwa kapal-kapal dagang Asia Tenggara di masa awal sudah ada yang berukuran besar. Penggalian purbakala yang mutakhir menunjukkan bahwa ada kapal yang panjangnya sampai 30 meter. $^{20}$

Jika menelusuri sumber sejarah seperti : Hikayat Banjar, Hikayat Lembu Mangkurat, Hikayat Raja-Raja Banjar dan Kotawaringin, serta Tutur Candi ${ }^{21}$, maka disebutkan mata rantai jaringan perdagangan kapal-kapal besar China telah terbentuk, yakni jenis Wangkang dan Banawa antara Keling dan Surabaya, Giri, Gresik, Kudus di Jawa Timur dengan Banjarmasin.

Jaringan perdagangan dimulai Empu Jatmika sebagai anak saudagar Keling, pendiri tahta di Negara Dipa, dan Raden Sekar Sungsang alias Ki Mas Lelana, anak angkat juragan Balaba dari Surabaya, pendiri tahta Negara Daha. Empu Jatmika membangun bandar di Muara Rampiau, dan telah masuk dalam jaringan perdagangan Majapahit. ${ }^{22}$ Menurut M. Idwar Saleh, letak Muara

${ }^{19}$ M.A.P. Meilink-Roelofsz, 1962, Asian Trade and European influence in the Indonesian archipelago between 1500 and about 1630, Deh Haag, Martinus Nijhoff, dalam A.B. Lapian, 1997, Dunia Maritim Asia Tenggara, dalam Sejarah Indonesia Penilaian Kembali Karya Utama Sejarwan Asing, Depok-Jakarta: Pusat Penelitian Kemasyarakatan dan Budaya Lembaga Penelitian Universitas Indonesia, hlm. 19. Tentang Pelayaran dan perdagangan Nusantara lihat O.W. Wolters, 2011, Kemaharajaan Sriwijaya dan Perniagaan DuniaAbad III-Abad VII, Jakarta: Komunitas Bambu, hlm. 19-23. Mengenai Kapal-Kapal Besar dibuktikan secara telaah sastra oleh Irawan Djoko Nugroho. Lihat Irawan Djoko Nugroho, 2011, Majapahit Peradaban Maritim Ketika Nusantara Menjadi Pengendali Pelabuhan Dunia, Jakarta: Suluh Nuswantara Bakti, hlm. 281.

${ }^{20}$ Y.P. Manguin dan Nurhadi, 1987, Perabu Karam di Situs Bukit Jaras, Propinsi Riau. Sebuah Laporan Sementara, dalam A.B. Lapian, Loc.cit

${ }^{21}$ Menurut Maharsi Resi, dasar konsep karya sastra sejarah Nusantara pada hakekatnya adalah mengutamakan kebenaran seperti yang diterima atau dilihat oleh masyarakat itu sendiri. Kebenaran dalam karya sastra sejarah ini tidak lebih hanya merupakan kebenaran yang bersifat subyektif daripada kebenaran obyektif. Konsep sejarah ini hanya dipahami berdasarkan perkembangan sejarah masyarakat pendukungnya. Karya sastra sejarah memberikan sumbangan kearah identitas suatu bangsa. Lihat Maharsi Resi, 2010, Islam Melayu VS Islam Jawa, Menelusuri Jejak Karya Sastra Sejarah Nusantara, Yogyakarta: Pustaka Pelajar, hlm. 6-7. Oleh sebab itu, berbagai versi tentang Hikayat Banjar dan Tutur Candi yang muncul pada era Kesultanan Banjar sejak abad ke-17 merupakan karya sastra sejarah yang memperlihatkan identitas Bangsa Banjar.

${ }^{22}$ Denys Lombard, 2005, Nusa Jawa: Silang Budaya, Jaringan Asia, Jilid II, diterjemahkan oleh Winarsih Partaningrat Arifin, et.al, Jakarta: Gramedia Pustaka Utama, hlm. 40. Menurutnya, 24 negeri yang disebut dalam Nagarakartagama, mencakup kawasan pantai selatan, barat dan utara Kalimantan. Diantaranya; Kutai, Pasir, Baritu, Kuta Waringin, Lawai, 
Rampiau di sekitar Pematang Penyaungan dan sekitar kampung Marampiau Kecamatan Candi Laras Selatan. ${ }^{23}$ Selanjutnya, Raden Sekar Sungsang mendirikan bandar di Muara Bahan. Hikayat Banjar telah menyinggung tentang Surabaya, Gresik dan Giri. Surabaya sejak abad ke-14 sudah merupakan pelabuhan. ${ }^{24}$

Berdasarkan bukti-bukti arkeologis, berbagai temuan keramik di perairan Sungai Nagara dan Sungai Bahan, ${ }^{25}$ perbandingan Hikayat Banjar dengan Tutur Candi, dan Babad Demak. (Hikayat Demak), Babad Tanah Jawi, Riwayat Sunan Giri, disertai kedekatan geografis Jawa Timur dengan Banjarmasin, juga pesatnya arus perdagangan maritim pada periode abad ke-15, maka sudah dipastikan Raden Sekar Sungsang, anak Juragan Balaba, ${ }^{26}$ merupakan pedagang Muslim yang mencoba membangun jaringan kuasa (power) di istana Negara Daha. Namun, karena kekuatan komunitas Hindu-Budha serta masih banyaknya komunitas Dayak; Biaju-Ngaju, Maanyan, Lawangan dan Bukit yang memiliki kepercayaan Kaharingan dan Balian, maka penyebaran Islam secara struktural oleh Sekar Sungsang mengalami kegagalan.

Kapuhas, Sambas, Buruneng yang mestinya sama dengan Brunei....wilayah-wilayah tersebut masuk dalam Jaringan dagang, dan tidak langsung diurus oleh pegawai-pegawai Majapahit.

23Jumiarti, 2003, Keberadaan Muara Rampiau di Kalimantan Bagian Tenggara Sebagai Bandar Perdagangan Pada Abad XIV Sampai Akbir Abad ke XV, Skripsi, Program Studi Pendidikan Sejarah Jurusan P.IPS FKIP UNLAM, Banjarmasin, hlm. 32, bandingkan dengan M. Idwar Saleh, 1986, Banjarmasih, Banjarmasin: Museum Negeri Lambung Mangkurat, hlm. 21, lihat juga Ismadi Dahri, 1991, Asal-Usul Kampung Marampiau, t. hlm, juga dalam Tim Peneliti, 2000, Umur Candi Laras Dalam Panggung Sejarah Indonesia Kuno, Banjarbaru, Balai Arkeologi, hlm. 36.

${ }^{24}$ Denys Lombard, 2005, Nusa Jawa : Silang Budaya Kajian Sejarah Terpadu Bagian I : Batas-Batas Pembaratan, diterjemahkan Winarsih Partaning Arifin, et.al, Jakarta: Gramedia Pustaka Utama, hlm. 37.

${ }^{25}$ Berbagai temuan keramik di sepanjang perkampungan tepian Sungai Barito hingga ke Sungai Tabalong, menunjukkan adanya aktivitas pedagang-pedagang China Muslim, yang sesuai dengan Berita Dinasti Ming, bahwa dalam abad ke-14 komunitas Banjarmasin telah mengganti tempat makannya dari daun dengan piring porselen dan sejenisnya.

${ }^{26}$ Menurut versi Hikayat Banjar, Sekar Sungsang adalah anak angkat Juragan Balaba, ia seorang anak dari Ratu Negara Dipa yang bernama Puteri Kalungsu, sementara versi Tutur Candi, Sekar Sungsang yang merantau ke Surabaya dan menikah dengan perempuan Surabaya memiliki anak yang bernama Sekar Panji.Ketika kembali ke Negara Dipa ia kawin dengan Puteri Kabuwaringin (versi Hikayat Banjar ia kawin dengan Puteri Kalungsu-ibunya sendiri). Sekar Panji menikah dengan anak Sunan Giri. Sunan Giri anak asuh dari Nyai Suta Pinatih (Nyai Minasih). Nyai Suta Pinatih, Syahbandar di Giri dan seorang Muslimah. Sementara Juragan Balaba kemungkinan besar adalah anak buah Nyai Suta Pinatih yan juga Muslim. 
Menurut Siti Chamamah, unsur Islam dalam Hikayat Raja-Raja Banjar dan Kota Waringin adalah sebagai pemberi benih. ${ }^{27}$ Bahwa Islamisasi Banjarmasin tidak bisa dilepaskan dari Sunan Giri, yang sangat aktif dalam melakukan aktivitas dakwahnya dalam abad ke-15. ${ }^{28}$ Sunan Giri dan Sunan Bonang dalam abad ke-15 telah berdakwah ke Muara Bahan. ${ }^{29}$

Sunan Giri dan Sunan Bonang membentuk jaringan perdagangan dengan komunitas Bakumpai, dibawah Raden Sira Panji Kesuma, anak Raden Sekar Sungsang dengan Puteri Kalungsu, ratu Negara Dipa.

Menurut Ricklefs, yang mengambil sumber Babad Tanah Jawi menyebutkan bahwa "Sunan Giri adalah anak angkat seorang saudagar wanita". ${ }^{30}$ Danys Lombart, ${ }^{31}$ Oemar Zainuddin, ${ }^{32}$ dan Hikayat Banjar sangat jelas memaparkan peran Nyai Suta (Ageng, Gde) Pinatih, seorang anak bangsawan China Muslim dari Palembang, ibu angkat Sunan Giri yang berperan aktif dalam perdagangan hingga ke Banjarmasin..$^{33}$

Jika melihat berbagai bukti historis, maka jaringan pedagang dari Surabaya, Gresik, Giri dan Kudus, tidak bisa dilepaskan dari jaringan sosial pedagang-pedagang China Muslim, yang aktif melakukan perdagangan internasional, sejak Laksamana Cheng-Ho diutus kaisar dari Dinasti Ming, yakni Kaisar Yong-lee. Kaisar ketiga dinasti Ming ini merupakan kaisar China

${ }^{27}$ Siti Chamamah Soeratno, 1997, Hikayat dan Syair "Penyimpan "Data Sejarah, Suatu Tinjauan Susastra, dalam Sejarah Indonesia Penilaian Kembali Karya Utama Sejarawan Asing, DepokJakarta: Pusat Penelitian Kemasyarakatan dan Budaya Lembaga Penelitian Universitas Indonesia, hlm. 153.-. 157.

${ }^{28} \mathrm{Ibid}$. Islam merupakan pemberi benih dari tumbuh berkembangnya peradaban baru, yang bersandarkan pada ajaran Al-Qur'an, Hadist Nabi, dan Ijma' Ulama.

${ }^{29}$ Muhammad Syamsu As, 1999, Ulama Pembawa Islam di Indonesia dan Sekitarnya, Jakarta: Lentera, hlm. 50-51. Lihat juga, Aminuddin Kasdi, Kepurbakalaan (Sunan Giri Sosok Akulturasi Kebudayaan Jawa Hindu dan Islam Pada Abad 15-16), IAIN Surabaya, 1987, hlm. 32. Lihat juga Ridin Sofwan, et.al,2004, Islamisasi di Jawa, Wali Songo, Penyebar Islam di Jawa Menurut Penelitian Babad, Yogyakarta, Pustaka Pelajar. hlm. 64

${ }^{30}$ M.C. Ricklefs, 1993, Sejarah Indonesia Modern, Jogyakarta: Gadjah Mada University Press, hlm. 13

${ }^{31}$ Denys Lombart, Op.cit, hlm. 43

${ }^{32}$ Oemar Zainuddin, 2010, Kota Gresik 1896-1916, Sejarah Sosial Budaya dan Ekonomi, Jakarta: Ruas, hlm. 19.

${ }^{33}$ Sekali lagi, Hikayat Banjar tidak memberikan mata rantai pengkisahan antara Sekar Sungsang dan Nyai Suta Pinatih. Padahal Tutur Candi, menunjukkan sebuah kisah adanya hubungan antara Sunan Giri dengan Sekar Sungsang. 
yang beragama Islam. ${ }^{34}$ Pedagang-pedagang China Muslim dari Kanton, tentu telah sampai pula ke Jawa Timur dan aktif berdagang hingga ke Banjarmasin sejak abad ke-15. ${ }^{35}$ Jaringan pedagang China dan Muballigh lainnya, yang berpusat di Surabaya, Gresik, Giri dan Kudus berhasil melakukan Islamisasi pada orang-orang Biaju-Ngaju-Bakumpai. ${ }^{36}$

Komunitas Bakumpai berhasil menyerap keahlian dagang para pedagang yang datang. ${ }^{37}$ Kemudian bersama komunitas Negara-AlabioAmuntai serta Kalua membangun jaringan perdagangan dari hulu-hulu Sungai di pedalaman ke muara-muara Sungai hingga ke Bandar Masih yang bertumbuh pada awal abad ke-16.

Komunitas pedagang Melayu yang dipimpin Patih Masih, seorang saudagar Melayu, orang besarnya di muara Kuin, membangun jaringan dengan komunitas Rantauan Bakumpai, dan jaringan pedagang di sekitar bandar Muara Bahan, serta melakukan komunikasi aktif dengan Bububan Tutus Raja-Raja, khususnya Pangeran Samudera, sehingga berhasil membangun jaringan kuasa di Kuin, Bandar Masih. Untuk memperkuat legetimasi politiknya, kuasa Bandar Masih, membangun relasi dan jaringan dengan Kesultanan Demak.

${ }^{34}$ Tan Ta Sen, 2010, Cheng-Ho Penyebar Islam dari China ke Nusantara, Jakarta: Kompas, hlm. 228-230.

${ }^{35}$ Sumber penting tentang Banjarmasin adalah berita-berita dari Dinasti Ming, sejak abad ke- 14. Lihat W.P. Groneveldt, Nusantara Dalam Catatan Tionghoa, Jakarta: Komunitas Bambu, hlm. 148-149.berdasarkan penggalian arkeologis situs makam Pangeran Surainsyah di Kuin Banjarmasin pada tahun 1984, ditemukan berbagai peti jenazah penuh ukiran, lazimnya peti jenazah orang-orang China. Lihat Gunadi Kasnowihardjo, et.al, 2006, Kajian Reka Ulang Replike Keraton Banjar di Kuin, Dinas Kebudayaan dan Pariwisata pemerintah Propinsi Kalimantan Selatan, hlm. 51

${ }^{36}$ Schwaner, dalam Helius Syamsuddin, Pegustian dan Temenggung, Akar Sosial, Politik, Etnis, dan Dinasti. Perlawanan di Kalimantan Selatan dan Kalimantan Tengab 1859-1906, Jakarta : Balai Pustaka, hlm. 45

${ }^{37}$ Route pelayaran memperlihatkan jaringan perdagangan maritim, juga menentukan pedagang-pedagang yang datang dan pergi di Banjarmasin. Route perdagangan dapat ditempuh melalui Malaka - Kalimantan Selatan (Banjarmasin) - Sulawesi Selatan ke Maluku. Lihat L.C. van Dijk, 1862, Het Neerlands vroegste betrekekingen met Borneo; Solo-Archipel, Cambodja, Siam en Cocbin - China. Konflik internal Mataram Islam abad ke-17 menyebabkan jalur perdagangan pindah ke Makassar dan Banjarmasin. Lihat D.H. Burger, 1983, Sejarah Ekonomi Indonesia dari Segi Sosiologi Sampai Akbir Abad XIX, disusun kembali oleh Prajudi Atmosudirdjo, Jakarta: Pradnya Paramita, hlm. 66.. 
Banjarmasin dalam tahun 1520 telah membayar upeti kepada Demak. ${ }^{38}$ Syarat dari hubungan pembentukan relasi dan jaringan ini, merupakan bagian dari sebab khusus Islamnya Pangeran Samudera, yang kemudian bergelar Sultan Suryanullah atau Sultan Suriansyah. ${ }^{39}$ Pengucapan syahadat oleh Pangeran Samudera sekedar legitimasi formal yang menandai telah berdirinya Kesultanan Islam sekitar tahun 1524, sementara menurut M. Idwar Saleh tahun 1526. Kemungkinan besar, Pangeran Samudera adalah salah seorang keturunan Sekar Sungsang yang telah mengakui agama Islam, sehingga ia dibuang ke Pulau Halalak. Kemudian dia berkolaborasi dengan komunitas Bakumpai dan pedagang-pedagang di Muara Bahan, serta mendapat dukungan penuh dari komunitas Melayu di Muara Banjar.

Kesultanan Banjarmasin yang eksis sejak awal abad ke-16 mengayomi komunitas pedagang, ${ }^{40}$ sekaligus sebagai kerajaan yang mengandalkan perdagangan lada, ${ }^{41}$ karena para bangsawan Kesultanan Banjar merupakan patron yang sangat diandalkan dalam segala aktivitas perdagangan. Akibat kemajuan perkebunan dan perdagangan lada, khususnya sejak abad ke-17 dan 18 Kesultanan Banjar berhasil membentuk dan mengkoordinir jaringan

${ }^{38}$ Lihat H.T. Colenbrander, 1925, Koloniale Gescheidenis II, Den Haag. hlm. 114. Lihat juga Encyclopeidie Nederlands Indie, hlm. 135. Lihat juga M. Idwar Saleh, tt, Sedjarah Bandjarmasin, Bandung: Balai Pendidikan Guru. hlm, 29.

${ }^{39} \mathrm{~J}$. Hageman, Bijdrage tot de gescheidenis van Borneo,TBG, 1857, hlm. 239. Lihat juga Meyer, Indische Gids 1899, I, hlm. 280, Mallinckrodt, 1925, Kolonial Tijddschrift, hlm. 266, Mussellein, Bijdragen K1, 1888, hlm. 14.

${ }^{40}$ Perdagangan era Islam dilindungi para Sultan Islam. Lihat B. Schriecks, Indonesian Sociological Studies, Bab II, Ruler and Realm in Early Java, hlm. 113. Dalam konteks ini, Kesultanan Banjar sangat berkepentingan melindungi para pedagang, karena pada dasarnya Kesultanan Banjar pada mulanya merupakan Kesultanan yang mengandalkan perdagangan laut maupun sungai.

${ }^{41}$ Syahbandar yang makmur dalam mengatur perdagangan lada, bernama Godja Babouw, berkebangsaan Keling. Lihat M. Idwar Saleh, Banjarmasin, Op.cit, hlm. 54. Lihat juga Contract Wegens d'E Comp. met die van Martapoera gemaeckt. Tertulis ' Ick Retnadij Ratja alias Codia Babouw Sabandar des Konings van banjermassin in Martapoera' dalam Surat-surat Perjanjian antara Kesultanan Bandjarmasin dengan Pemerintahan V.O.C. Bataafse Republik, Inggeris dan Hindia-Belanda 1635-1860: Jakarta, Arsip Nasional Republik Indonesia Kompartimen Perhubungan Dengan Rakyat, hlm. 2. Lihat juga, persaingan perdagangan lada antara China dan Belanda.dalam Goh Yoon Fong, 1969, Trade and Politics in Banjarmasin 1700-1747, Thesis, London, hlm. 210 . 
pedagang dari pedalaman ke muara sungai, dari muara sungai hingga ke muara sungai Barito yang langsung bersambung dengan Laut Jawa. ${ }^{42}$

Pada akhir abad ke-18 dan pertengahan abad ke-19, pedagang-pedagang Bakumpai, Nagara, ${ }^{43}$ Alabio, Amuntai dan Kalua telah langsung berhubungan dengan cokung-cokung China. ${ }^{44}$ Pedagang-pedagang lokal mengalami mobilitas vertikal, yang juga memiliki posisi sebagai kelas menengah di Banjarmasin. Mereka sebagian menjadi Haji, dan ikut mendinamisasi komunitas Banjarmasin. ${ }^{45}$

Saluran Islamisasi melalui Perkawinan berhasil membentuk jaringan emosional Bububan. ${ }^{46}$ Perkawinan dilakukan oleh individu-individu pedagang

${ }^{42}$ Pada zaman Tome Pires, Banten merupakan tempat pedagang-pedagang dari Palembang, Pariaman, dari Lawe dan Tanjung Pura (Kalimantan Selatan; Banjarmasin). Artinya, pedagang Banjarmasin ikut dalam arus perdagangan internasional, selain aktif berdagang ke luar negeri, juga selalu dikunjungi para pedagang dari berbagai bangsa. Lihat A.B. Lapian, 2008, Pelayaran dan Perniagaan Nusantara Abad ke-16 dan 17, Jakarta: Komunitas Bambu, hlm. 49. Lihat pula Uka Tjandrasasmita, 2009, Arkeologi Islam Nusantara, Jakarta: KPG (Kepustakaan Populer Gramedia) bekerjasama dengan Ecole francaise d'Extreme-Orient dan Fakultas Adab dan Humaniora UIN Syarif Hidayatullah, hlm. 39. Pada abad ke-18, tahun 1702, perdagangan Banjarmasin sangat ramai. Lihat Francois Valentijn, 1726, Beschrijving van het eiland Borneo, en onzen handel aldaar. Oud en Niew Oost Indien. III, Dordrech: van Bram, dalam M. Idwar Saleh, Op.cit, hlm. 56

43 Jiwa dagang dan keahlian sebagai pengrajin besi komunitas Negara dijelaskan oleh Anthony Reid. Lihat Anthony Reid, 1992, Asia Tenggara Dalam Kurun Niaga 1450-1680, Jilid I : Tanah di Bawah Angin, Penerjemah Mochtar Pabottinggi, Jakarta: Yayasan Obor Indonesia, hlm. 118

${ }^{44}$ Mayor William Thorn, 2004, Penaklukan Pulau Jawa-Pulau Jawa di abad Sembilan belas dari amatan seorang serdadu Kerajaan Inggeris, penerjemah Noviatri, Jakarta: PT. Elex Media Komputendo, hlm. 304

${ }^{45} \mathrm{Abad}$ ke-17, Urang Banjar sudah ada yang pergi Haji ke Mekkah. Lihat Ramli Nawawi, 1980/1981, Sejarah Pendidikan di Kalimantan Selatan, Banjarmasin: Departemen Pendidikan dan Kebudayaan Kalimantan Selatan, hlm. 13 Perjalanan haji abad 17, 18 dan 19 dari Nusantara dengan kapal layar ke Jeddah mencapai waktu enam (6) bulan lamanya. Lihat K.N. Chaudhuri, 1989, Trade And Civilization in The Indian Ocean An Economic History From The Rise of Islam to 1750, Cambridge: Cambridge University Press, hlm. 46, dalam M. Dien Majid, 2008, Berhaji Di Masa Kolonial, Jakarta: CV. Sejahtera, hlm. 51

${ }^{46}$ Meijer sangat jelas melukiskan perubahan agama komunitas Dayak Biaju-Ngaju dari Kaharingan kepada agama Islam. Lihat J.J. Meijer, 1949, Blanken of Borneo. Herinneringen van J.J. Meijer. Naverteld en van een inleiding voorzien door G.L. Tichelman. Amsterdam: A.J.G. Stenghold,c) hlm. 52-54, 59-63 dalam Helius Syamsuddin Op.cit, hlm. 58. Lihat pula Diah Ratna Wulan, 2008, Komunitas Bakumpai Di Buntok. (Barito Selatan) Dari Abad Ke-15 Hingga Dasawarsa Pertama Abad Ke-21, Skripsi, Banjarmasin: Program Studi Pendidikan Sejarah Jurusan P.IPS FKIP UNLAM, hlm 21-30. 
Muslim dengan perempuan-peremuan dari etnis Biaju-Ngaju-Bakumpai, Maanyan, Lawangan, dan Bukit. Perkawinan juga dilakukan para Ulama, dengan berbagai etnis di Banjarmasin. ${ }^{47}$ Pada abad ke-18 hingga abad ke-19 ditandai munculnya Bububan Syekh Muhammad Arsyad Al-Banjary, dan Bububan Anak Cucu Sepulub dari Syekh Abdul Hamid Abulung, dan Bubuhan Datu-Datu lainnya.

Perkawinan juga dilakukan oleh Bubuhan Tutus Raja-Raja Banjar, dengan berbagai etnis di Banjarmasin, baik etnis Dayak, maupun dengan perempuan dari etnis Melayu, Jawa, Bugis, Makassar dan Wajo. Hasil perkawinan Bububan Tutus Raja-Raja Banjar sangat cepat memberi andil terhadap perkembangan Islam di Banjarmasin sejak abad ke-16 hingga abad ke-19.

Saluran Islamisasi melalui Tasawuf dan Tarekat di Banjarmasin melalui saluran Tasawuf Sunni dan Tasawuf Falsafi. ${ }^{48}$ Saluran Tasawuf Sunni dipelopori Khatib Dayyan pada awal abad ke-16, dilanjutkan oleh Khatib Banun dari Bakumpai. ${ }^{49}$ Abad ke-17 muncul Ulama dari Balangan, yakni Syekh Zainal Abidin atau Datu Kandang Haji. ${ }^{50}$ Sementara di Rantau dipelopori Datu Ujung, dan menjelang akhir pertengahan abad ke-18, saluran Islamisasi

${ }^{47}$ Menurut Anthony Reid, para perempuan Banjarmasin yang telah menikah dengan pedagang-pedagang Muslim, sangat ketat dalam menjaga martabat diri dan suaminya jika telah menikah. Lihat Anthony Reid, Op.cit, hlm. 176. Lihat juga Daniel Beeckman, 1718, A Voyage to and from the Islands of Borneo in the East Indies, London. Dicetak kembali di London, Dawsons, 1973, hlm. 41. Kutipan ini dibuat Reid dengan mengambil sumber yang lebih tua yakni awal abad ke-18 (1718), meskipun juga dimuat oleh Valentijn 1726 III: 312, Low 1848: 196, dan Finlayson 1826: 309-310.

${ }^{48}$ Tentang Tasawuf Sunni dan Falsafi dapat ditelaah dari penjelasan Alwi Shihab. Lihat Alwi Shihab, 2009, Antara Tasawnf Sunni \& Tasawnf Falsafi, Akar Tasawuf di Indonesia, Jakarta: Pustaka Iman, hlm. 22

${ }^{49}$ Khatib Banun adalah mertua Sultan Hidayatullah (1570-1595). Bergelar Kyai Di Podok. Kemungkinan alumnus Pesantren Demak. Lihat Husni Abar, 2003, Panembahan Muda Aling (Datu Muning) Sebuah Studi Kasus tentang Kekuasaan dalam Masyarakat Banjar, Rantau: Pemerintah Kabupaten Tapin Kalimantan Selatan, hlm. 55. Jika kita hubungkan dengan kekerabatan antara Raden Sira Panji Kesuma sebagai tokoh Bakumpai dengan Sekar Sungsang yang memiliki anak di Giri, yakni Sunan Serabut, maka Khatib Banun kemungkinan masih ada hubungan dengan Raden Sira Panji Kesuma, karena itulah dalam rangka menyambung tali keluarga Sultan Hidayatullah kemudian kawin dengan anak Khatib tersebut. Hubungan jaringan kekeluargaan ini memberi gambaran posisi penting orang Bakumpai dalam Islamisasi Banjarmasin.

${ }^{50}$ K.H. Husein Nafarin, Datuk Kandang Haji, Banjarmasin Post, Banjarmasin: Jumat 14 Mei 2010, hlm. 1 
Tasawuf Sunni digerakkan oleh Syekh Muhammad Arsyad Al-Banjary. ${ }^{51}$ Awal abad ke-19 dan seterusnya dilanjutkan oleh zuriyat Syekh Muhammad Arsyad Al-Banjary.

Tasawuf Falsafi kemungkinan dimulai sejak awal abad ke-16 oleh Syekh Abdul Malik dari Aceh. ${ }^{52}$ Pada abad ke-17 muncul Ulama besar Tasawuf Falsafi, yakni Syekh Ahmad Syamsuddin Al-Banjary di Martapura. ${ }^{53}$ Akhir abad ke-17 dan awal abad ke-18, paham Tasawuf Falsafi dikembangkan Syekh Sirajul Huda atau Datu Sanggul, ${ }^{54}$ Datu Suban dan Datu Nurayya di kawasan Rantau. ${ }^{55}$ Sementara di Negara dilakukan oleh Syekh Muhammad Tahir, atau Datu Negara. ${ }^{56}$ Di Margasari, muncul Syekh Yusuf Khair. Sementara di Kelua oleh Syekh Muhammad Nafis Al-Banjary, yang terkenal dengan kitabnya Ad-Durun Nafis. ${ }^{57}$ Di Martapura oleh Syekh Abdul Hamid Abulung. ${ }^{58}$ Sementara di

${ }^{51} \mathrm{Abu}$ Daudi, 1996, Maulana Syekh Muhammad Arsyad Al-Banjari, Martapura: Sekretariat madrasah 'Sullamul Ulum' Dalam Pagar, hlm. 16. Lihat Juga Abu Daudi, 2003,Maulana Syekh Muhammad Arsyad Al-Banjary (Tuan Haji Besar), Martapura: Yayasan Dalam Pagar (YAPIDA), hlm. 44, Lihat pula Tim Sahabat, 2008, Cerita Datu-Datu Terkenal Kalimantan Selatan, Kandangan: Toko Buku dan Penerbit Sahabat., hlm. 44.

${ }^{52}$ Tim Sahabat, Ibid. hlm. 67. Makam Syekh Abdul Malik ada di kompleks Makam Sultan Suriansyah Kuin, Banjarmasin. batu nisannya berciri Aceh dan Gujarat.

${ }^{53}$ Abdurrahman, 1992, Menguak. Sisi-Sisi Gelap Proses Perkembangan Islam di Kalimantan Selatan, Makalah dalam Seminra Sejarah Program Studi Pendidikan Sejarah FKIP UNLAM, Banjarmasin, hlm. 19

${ }^{54}$ Lihat Abdurrahman, 1999, Upaya Menyingkap Misteri Datu Sanggul Tokoh Legendaris atan Tokoh Sejarah, Makalah, disampaikan pada acara bedah buku Biografi Datu Sanggul, Rantau: 25 November 1999. hlm. 8

${ }^{55}$ H. Muhammad Marwan, 2010, Manakib Datu Suban, Kandangan: Tim Sahabat, hlm. 11-14. Lihat pula Ahmad Gazali Usman, 1999, Riwayat Datu Sanggul dan Para Datu-Datu, Rantau: Pemerintah Kabupaten Dati II Tapin, hlm. 104

${ }^{56}$ Fahrurraji Asmuni, 2002, Cerita Datu-Datu Terkenal Kalimantan Selatan, Kandangan: Toko Buku \& Penerbit Sahabat, hlm. 63. Lihat juga Yustan Aziddin, etal, 1980/1981, Cerita Rakyat Daerah Kalimantan Selatan, Jakarta: Departemen Pendidikan dan Kebudayaan Proyek Inventarisasi dan Dokumentasi Kebudayaan Daerah, hlm. 59-70

${ }^{57}$ Tim Alih Tulisan, 2001, Inilah Kitab Yang Dinamakan Dia Durrun Nafis (Mutiara Yang Indab) Pada Menjelaskan Wabdatul Af'al, Asma dan Zat-Zat Taqdis, Tabalong: Kerjasama Komunikasi dan Silaturrahmi Keluarga Alumni PMII Kabupaten Tabalong dengan Pemerintah Kabupaten Tabalong, hlm. 101 , Lihat juga M. Laily Mansur, 1982, Kitab Ad-Durun Nafis Tinjauan Atas Suatu Ajaran Tasawuf, Banjarmasin: Hasanu, hlm. 5. , Lihat pula A. Gazali Usman, 1989, Orang Banja Dalam Sejarah, Diktat, Program Studi Pendidikan Sejarah FKIP UNLAM, hlm. 65 .

${ }^{58}$ Chairunnisa, 2003, Penokoban Syekh Abdul Hamid Abulung Sebagai Penyebar Ajaran Wabdatul Wujud di Kalimantan Selatan Pada Awal Abad XVIII dan Pada Awal Abad XIX, Skripsi: 
kawasan Pelaihari dikenal Datu Insad, Syekh Samada dan Datu Mastanian. Di Pulau Datu, Batakan dikenal Datu Pamulutan, Syekh Muhammad Taher, yang berasal dari Martapura.

Jaringan Tasawuf Sunni dan Falsafi sebagian dikembangkan Ulama Jaringan Haramayn, yang berasal dari luar Banjarmasin, dan sebagian Ulama Jaringan Haramyn yang memang belajar di Mekkah dan Madinah. Sementara itu, jaringan Tarekat, sejak awal abad ke-16 hingga abad ke-19 berkembang di Banjarmasin. ${ }^{59}$ Tarekat itu antara lain; tarekat Syattariyah, Naqsabandiyah, Khalwatiyah, Sazaliyyah dan Sammaniyah, juga dikembangkan jaringan Ulama dari golongan Tasawuf.

Dalam perkembangan Tasawuf, Kesultanan Banjar memberikan ruang yang luas, bagi Ulama yang mengedepankan Syari'at Islam, dengan faham Sunni (Ahlus-Sunnah Wal-Jama'ah), sehingga syiar Islam terpancar dari ramainya mesjid yang menjadi tempat ibadah ummat Islam. Dalam Hikayat Banjar disebutkan bahwa Sultan Mustain'billah membangun Mesjid di Martapura (daerah Tambangan dan Kampung Melayu), dan ikut sholat Jum'at beserta para menterinya.

Birokrasi pemerintahan Kesultanan Banjarmasin pada fase awal, sejak abad ke-16 hingga pertengahan abad ke-18, belum secara langsung berfungsi dalam Islamisasi. Namun upaya Tuan Penghulu, Khatib Dayyan dan Khatib Banun membangun berbagai mesjid memberikan bukti kiprah Kesultanan dalam membangun komunitas Muslim. ${ }^{60}$ Baru pada akhir abad ke-18, Birokrasi pemerintahan Kesultanan Banjarmasin menempatkan Lembaga 'Mabkamah Syariah' sebagai birokrasi peradilan, yang justru berperan mengembangkan jaringan Islamisasi ke berbagai pelosok Banjarmasin melalui peran Mufti, Qadhi, Khalifah, Khatib, Penghulu dan Bilal. ${ }^{61}$ Birokrasi ini dimantapkan oleh

Banjarmasin, Program Studi Pendidikan Sejarah Jurusan Pendidikan IPS FKIP UNLAM, hlm. 22.

59Jaringan Ulama Tarekat dan Jaringan Ulama Haramyn dengan lengkap telah dikaji oleh Rahmadi. Lihat Rahmadi, 2010, Jaringan Intelektual Ulama Banjar Abad XIX dan XX (Studi Tentang Proses, Pola dan Ekspansi Jaringan), Banjarmasin: Antasari Press, hlm. 249-267.

${ }^{60}$ Sebuah Cerita rakyat dari Barabai "Kisah Berdirinya Masjid Palajau" menjelaskan kedatangan Ulama dari Jawa yang datang ke Kuin Banjarmasin, dipimpin Malik Ibrahim membangun Mesjid Palajau pertengahan abad ke-16. Malik Ibrahim juga membangun Mesjid lainnyasebanyak 10 buah termasuk di Kelua dan Negara. Menurut Penulis nama Malik Ibrahim adalah identik dengan Khatib Dayyan.

${ }^{61}$ Tentang posisi Penghulu dan tugas-tugasnya, khususnya pada zaman Belanda, lihat G.F. Rijfer, tt, Beberapa Studi Tentang Sejarah Islam di Indonesia 1900-1950, Penerjemah Tudjimah dan Yessy Augusdin, hlm. 67. 
Sultan Adam Al-Wasiku Billah pada awal abad ke-19 melalui konstitusi yang dikenal sebagai UU Hukum Sultan Adam. ${ }^{62}$ Jaringan Mabkamah Syariah dengan Islamisasinya dipegang oleh Bubuhan Tuan Surgi Syekh Muhammad Arsyad AlBanjary.

Pada abad ke-15 hingga abad ke-16, jaringan pendidikan di Banjarmasin masih bersifat personal dan komunitas yang terbatas. Dikembangkan para pedagang dan para Muballigh. Jaringan pendidikan tersistematis sejak abad ke17 oleh pesantren Datu Kandang Haji, Syekh Zainal Abidin dengan sistem pengajian Balangan, di Balangan. Di Rantau pada akhir abad ke-17, jaringan Datu Ujung di Banua Halat, mengembangkan pesantren bagi etnis Bukit setempat, dan bagi komunitas Islam dilindungi oleh kampung Garis Halat. Di Dalam Pagar, yang dibatasi garis Sungai Halat-Astambul, Datu Kalampayan, Syekh Muhammad Arsyad Al-Banjary dengan pengajian sistem Sorogan-nya, yang difasilitasi oleh Sultan Nata Alam berhasil mendidik jaringan Bubuhan Kelurganya menjadi Tuan Guru di Martapura sekaligus putera-putera Banjar dari berbagai suku bangsa yang sebagian besar juga menjadi Taun Guru. Syekh Muhammad Arsyad Al-Banjary mengarang berbagai Kitab untuk dipelajari di pesantrennya. Kitab-kitab itu seperti; Sabilal Mubtadien, Kaulul Mukhtasar, Tubfaturragibien, Kanzul Ma'rifah dan lain-lain menjadi kitab utama dalam pengaiian di Pesantren Dalam Pagar. ${ }^{63}$ Pola pendidikan demikian terus dilanjutkan oleh zuriat Syekh Muhammad Arsyad Al-Banjary dan murid-muridnya sampai sekarang.

Saluran kesenian, dikembangkan oleh Bububan Tutus, Bububan Tuan Guru dan Bububan Jaba. Kesenian Wayang Kulit Banjar, Wayang Orang, Wayang Gong, Ba'da Muluk, Mamanda, Madihin, Balamut, Barudat, japen, dan lain-lain, ${ }^{64}$ sebagian besar merupakan pengaruh dari Sumatera sejak abad ke-17

${ }^{62}$ Lihat Serie L. Borneo No. 18 Oendang-Oendang Soeltan Adam, 1835.

${ }^{63} \mathrm{Abu}$ Daudi, 2003, Op.cit, hlm. 78-84. Lihat pula, Abdurrahman, "Mengenal Karya Tulis Ulama Banjar (Bagian IV), Menelusuri Karya Syekh Mubammad Arsyad Al-Banjar”, Dinamika Berita 21 November 1991. Lihat pula, H.W. Muhammad Shaghir Abdullah, 1992, Syekh Muhammad Arsyad Al-Banjary, Matahari Islam, Pondok Al-Fathanah, hlm. 41-43. Pemikiranpemikiran Syekh Muhammad Arsyad Al-Banjary dalam bidang Tauhid dan Tasawuf, khususnya pada kitab-kitab: Tubfaturragibien, Maz̧haqb Ablus-Sunnah wal-Jamaah, Qaulul-Mukhtashar, FathulRahman, dan Kanzul-Ma'rifah diuraikan oleh Prof. H.M. Asywadie Syukur, LC, Lihat M. Asywadie Syukur, 2009, Pemikiran-Pemikiran Syekh Muhammad Arsyad Al-Banjary Dalam Bidang Taubid dan Tasawuf, Banjarmasin: Center For Community Development Studies (COMDES) Kalimantan. hlm. xi.

${ }^{64}$ Amir Hasan Bondan, 1953, Suluh Sedjarah Bandjarmasin, Pertjetakan Fadjar, hl. 132138. Uraian tentang kesenian Lamut dijelaskan Tim Depdikbud. Lihat Tim Depdikbud, 1987/1988, Kesenian Rakyat Kalimantan Selatan Lamut', Banjarmasin: Dedikbud, hlm. 6. Lihat 
hingga abad ke-19, kecuali Wayang Kulit Banjar yang memang berasal dari Jawa, khususnya dari Demak. Kesenian Baayun Maulud, di Mesjid Banua Halat Rantau sebagai peninggalan dari Datu Ujung. ${ }^{65}$ Sementara tradisi di Tambak Anyar, Martapura yang diselingi syair "Huwal-Awwal Damai Dandam", dan syair "Hasan Husein" menunjukkan gejala adanya pengaruh Persia. ${ }^{66}$ Begitu pula dengan budaya membuat "Bubur Asyura" setiap tanggal 10 Muharram. Berbagai saluran kesenian Banjar, termasuk perubahan dalam seni lukis, ${ }^{67}$ seni pahat kaligrafi dalam rumah Banjar, ${ }^{68}$ menunjukkan kentalnya pengaruh Islam.

Ketika perang Banjar meletus pada tahun 1859, segenap Bubuhan Tutus, Tuan Guru dan Jaba berupaya mempertahankan eksistensi Kesultanan Banjarmasin, namun karena politik devide et impire, seperti munculnya intrik internal istana dan mitos pemisah Banjar - Dayak, yakni antara Banjar yang Islam dengan Dayak yang ; Kaharingan, Balian dan Kristen, mengakibatkan kekalahan Kesultanan Banjarmasin. Pada tanggal 11 Juni 1860 Kesultanan Banjarmasin dihapuskan oleh Belanda. Namun, muncul pretender Kesultanan Banjarmasin di hulu Barito, yakni Pangeran Muhammad Seman. Pangeran ini melakukan Islamisasi melalui jaringan sosial Bububan, dan berhasil menyebarkan Islam di sepanjang aliran hulu Sungai Barito, dari Buntok hingga kawasan Muara Teweh. Pesatnya Islamisasi akhir abad ke-19 di hulu Barito, disikapi oleh RMG (Rheinische Missiongesellschaft), bekerjasama dengan pemerintah kolonial Belanda untuk melakukan Kristenisasi di kawasan Kapuas. Bububan

juga tentang Rudat dalam M. Suriansyah ideham, et.al, 2005, Urang Banjar dan Kebudayaannya, Banjarmasin: Badan Penelitian dan Pengembangan Daerah Pemerintah Propinsi Kalimantan Selatan, hlm. 274.

${ }^{65}$ A. Gazali Usman, 2000, Tradisi Baayun Maulud 12 Rabiul Awal Di Mesjid Keramat Banua Halat Rantau-Kabupaten Tapin, Rantau: Pemerintah Kabupaten Daerah Tingkat II Tapin, hlm. 14.

${ }^{66}$ Naskah Syair Huwal-Awwal Damai Dandam ditemukan di kampung Tambak Anyar, Martapura. Ketika kelompok Maulid kampung Pematang Martapura melantunkan syair ini, jenis tarbang yang dipakai adalah tarbang Basar dan tarbang Pamadihinan, dengan langgam madihin. Syair ini dipergunakan untuk menolak penyakit dan mengharap pertolongan Allah Swt, syafaat Rasulullah Saw., dan memuji bela terhadap Hasan dan Husein binti Fatimah binti Rasulilah Saw.

${ }^{67}$ Yustan Aziddin, tt, Kesenian Tradisional Yang Berbubungan Dengan Kepercayaan Rakyat Daerah Kalimantan Selatan, Banjarmasin: Kanwil Depdikbud Propinsi Kalimantan Selatan, hlm. 13-22.

${ }^{68}$ M. Idwar Saleh, 1980-1981, Rumah Tradisional Banjar Rumab Bubungan Tinggi, Banjarbaru: Museum Negeri Lambung Mangkurat Propinsi Kalimantan Selatan, hlm. 41. Lihat Juga Amir Hasan Bondan, Op.cit, hlm. 140. 
Dayak Islam hulu Barito harus berlawanan dengan Bububan Dayak Kristen, yang sengaja dilakukan Belanda, dalam kerangka mengokohkan kolonialismenya di Banjarmasin. ${ }^{69}$

\section{Menjadi Banjar: Hasil Islamisasi Banjarmasin Dalam Naungan dan Peran Kesultanan Banjar}

Kecerdasan etnis Dayak Banjarmasin dalam menghadapi era globalisasi abad ke-15 yang dimotori pedagang-pedagang Islam ditandai dengan adaftasi, difusi, assimilasi, dan akulturasi kebudayaan Dayak dengan kebudayaan Islam. Etnis Biaju-Ngaju-Bakumpai mengambil peran dinamisator perubahan ekonomi, dari ekonomi subsistensi kepada ekonomi perdagangan, bukan saja sekedar perdagangan sungai, tetapi juga perdagangan maritim. Mereka berafiliasi dengan Bubuhan Tutus Raja-Raja Banjar, dan membentuk hubungan simbiosis dalam perdagangan, termasuk menghadapi persaingan dagang dengan China dan Belanda. ${ }^{70}$

Etnis Dayak; Biaju-Ngaju, Maanyan, Lawangan dan Bukit yang kemudian menerima Islam, bahkan kemudian secara cerdas, langsung menyerap ajaran-ajaran Islam di negeri Mekkah. Mereka menjadi Tuan Guru dan membangun komunitas Islam di wilayahnya. Jaringan Bubuhan Tuan Guru yang terbentuk setidak-tidaknya sejak awal abad ke-17, sedemikian rupa, dengan cerdas dan dinamis membangun sel-sel jaringan saluran Islamisasi, dan menjadikan Islam sebagai identitas baru.

Sungai sebagai sarana transportasi membentuk jaringan Bububan, Kepentingan dan Kuasa bagi komunitas Dayak. ${ }^{71}$ Bahasa Melayu (Banjar) sebagai bahasa Lingua Franca menjembatani komunikasi antar etnis Dayak dan

${ }^{69}$ Helius Sjamsuddin, 2001, Pegustian dan Tumenggung, Akar Sosial, Politik, Etnis, dan Dinasti Perlawanan di Kalimantan Selatan dan Tengah 1859-1906, Jakarta: Balai Pustaka, hlm. 260265

${ }^{70}$ Goh Yoon Fong, Loc.cit

${ }^{71}$ Tentang pentingnya sungai bagi urang Banjar telah dijelaskan dengan baik oleh M. Idwar Saleh. Lihat M. Idwar Saleh, 1983/1984, Sekilas Mengenai Daerah Banjar dan Kebudayaan Sungainya Sampai Dengan Akbir Abad - 19, Banjarbaru: Museum Negeri Lambung Mangkurat Propinsi Kalimantan Selatan, hlm. 2-7. Laporan Komisi Ilmu Pengetahuan Belanda tahun 1847, di kawasan tepian Barito telah bertumbuh kampung-kampung baru, dari hasil proses perdagangan dan Islamisasi Banjarmasin. Lihat Bambang Subiyakto dan Djoko Suryo, 2001, Pelayaran Sungai di Kalimantan Tenggara: Tinjauan Historis tentang Traansportasi Air Abad XIX, Sosiohumanika, Vol. 14 No. ! Januari 2001, Yogyakarta: Program Pasca Sarjana, hlm. 29 
etnis lainnya di Banjarmasin. ${ }^{72}$ Huruf Arab, bukan saja menjadi alat untuk komunikasi melalui tulisan, ${ }^{73}$ tetapi juga menjadi alat untuk menambah pengetahuan melalui kitab-kitab, yang dikarang cendekia Banjar, menggunakan huruf Arab berbahasa Melayu Banjar. ${ }^{74}$

Etnis Biaju-Ngaju, Maanyan, dan Lawangan yang tadinya beragama Kaharingan kemudian menjadi Dayak Islam. Sementara etnis Bukit yang tadinya memiliki kepercayaan Balian kemudian menjadi Dayak Bukit Islam. Sebagian komunitas batang Negara dan kelompok elite istana Negara Dipa dan Negara Daha yang berasal dari Jawa, serta sisa-sisa dari suz̨erinitas kuasa MelayuSriwijaya di Tanjung Tabalong hingga Margasari, ikut melakukan perubahan kepercayaannya dari Hindu-Budha kepada agama Islam. Hingga akhir abad ke19, Islamisasi Banjarmasin berhasil merubah komunitas Banjarmasin, dari ambang Barito hingga hulu Barito. Lembah-lembah Pegunungan Meratus, dan di kaki-kaki pegunungan itu, kemudian menjadi komunitas-komunitas Islam.

Etnis Dayak yang telah menerima Islam, kemudian secara cerdas melakukan adaftasi, difusi, assimilasi dan akulturasi kebudayaannya, daurhidupnya, dengan ajaran-ajaran Islam, menghasilkan format pribumisasi Islam. $^{75}$ Mereka ikut membangun Kesultanan Banjarmasin, dan sebagian

${ }^{72}$ Goerge Miller,1960, Plans and The Structure of Behavior, New York: Reinhart and Winston, hlm. 159. Lihat juga Gorys Keraf, 1984, Tata Babasa Indonesia, Ende-Flores: Nusa Indah, hlm. 22

${ }^{73}$ Surat-surat Sultan Sulaiman Saidullah kepada Gubernur Hindia Belanda, ditulis dengan indah serta kertas yang bermutu, dalam Mu'jizah, 2009, Iluminasi dalam Surat-Surat Melayu Abad ke-18 dan ke-19, Surat No.41, KPG, hlm. 125, naskah asli surat ini dicantumkan dengan lengkap dalam bentuk huruf Arab berbahasa Melayu-Banjar, dengan kertas terbaik, yang menunjukkan tingginya peradaban Banjarmasin berkah dari Islamisasi sejak abad ke-15.

${ }^{74}$ Lihat FSA. De Clereq, 1877, De Vroegste Gescheidenis van Bandjarmasin, dalam Tijdschrift voor Indisch Taal-Volken kunde, XXIV, hlm. 264. Lihat pula M. Zurkani Yahya, Bahasa Banjar Arkais Dalam Kitab Sabilal Mubtadin, Makalah, Disampaikan pada Diskusi Panel Bahasa Banjar Tanggal 24 Oktober 1992, Banjarmasin: Kelompok Studi Masyarakat dan Budaya Pusat Penelitian Universitas Lambung Mangkurat, hlm. 6. Dalam konteks ini bukan saja kitab Sabilal Mubtadin, yang menggunakan bahasa Melayu-Banjar, tetapi juga kitab Tubfaturragibien.dan kitabkitab lainnya.

${ }^{75}$ Menurut Syaiful Arif, pribumisasi tercipta karena keberhasilan budaya-agama hingga abad ke-16, karena bertemunya genius lokal dengan nilai-nilai universal. Pada titik inilah nilai budaya kita (Indonesia) mampu menggerakkan 'perintah historis'. Lihat Syaiful Arif, 2010, Refilosofi Kebudayaan Pergeseran Pascastruktural, Jogjakarta: Ar-Ruzz-Media, hlm. 333. Menurut pandangan penulis, pribumisasi Islam di Banjarmasin merupakan pertemuan genius lokal dengan nilai-nilai Islam yang mampu menampung semua kebutuhan batiniah pemeluknya, sehingga budaya Banjar sebagai bentuk refleksi tindakan bangsa Banjar dalam naungan sekaligus peran 
berhasil masuk dalam jaringan Tutus Raja-Raja Banjar ${ }^{76}$ karena hubungan perkawinan, atau status mereka yang memang sebagai Lelawangan, sekaligus pemangku Adat Dayak.

Dayak Islam sebagai 'orang dagang', ${ }^{77}$ bergabung dengan komunitas dagang Melayu- Malaka, dan disatukan oleh Kesultanan Banjarmasin. Akibat afiliasi dan kongsi dagang, serta hubungan dinamis yang kontinyu dengan Kesultanan Banjarmasin, menyebabkan identitas Dayak, lebur dalam identitas Banjar. Mereka yang membawa dagangan dari pedalaman membawa dagangannya ke Banjar, ${ }^{78}$ dan yang datang ke pedalaman mendapat sebutan datang dari Banjar. Sementara pedagang yang lama 'madam' di Banjar, telah mendapat status sebagai 'telah menjadi Urang Banjar'.

\section{Penutup}

Pola Islamisasi Banjarmasin sejak abad ke-15 hingga abad ke -19 melalui saluran-saluran Islamisasi; perdagangan, perkawinan, tasawuf dan tarekat, birokrasi pemerintahan, pendidikan serta kesenian, pada abad ke-15 hingga awal abad ke-16 sebagian besar melalui jalur bawah (Bottom Up), dan sejak pertengahan abad ke-16 sampai akhir abad 17, Kesultanan Banjar melalui Tuan Pengbulu dan para Sultan ikut bergerak melakukan syiar Islam melalui jalur-jalur Islamisasi, khususnya perdagangan dan perkawinan maka puncaknya

Kesultanan Banjar sejak awal abad ke-16 hingga abad ke-19. Untuk itu, memahami format realitas historis bangsa Banjar merupakan panggilan historis, sekaligus 'perintah historis', dengan asas dasarnya meningkatkan harkat dan martabat bangsa Banjar dan 'Tak- kan Melayu

\section{Banjar hilang di Bumi'.}

${ }^{76}$ Posisi Sultan dan Bubuhan Tutus Raja-Raja memiliki otoritas tertinggi, sekaligus akan berimplikasi pada upaya pengayoman ummat, sehingga kedudukan ini menjadi bagian penting dalam dinamika sosial politik di Nusantara. Lihat Uka Tjandrasasmita "The Arrival and Expansion of Islam in Indonesia in Relation to Southeast Asia, dalam Mulyanto Sumardi (ed.), International Seminar on Islam in Southeast Asia, dalam Ahmad M. Sewang, 2005, Islamisasi Gowa (Abad XVI Sampai Abad XVII), Jakarta: Yayasan Obor Indonesia, hlm. 7

${ }^{77}$ Konsep ini telah dikembangkan oleh W.F. Wertheim dalam "Religious Reform Movements in South and South East Asia" (Gerakan Pembaharuan Agama di Asia Selatan dan Asia Tenggara), Archive de Sociologie des Relegions, No. 12, 1961, Paris.

${ }^{78}$ Contoh orang Alabio berbicara dikutip oleh J. Mallinckrodt seperti berikut : "Ikam bundek (bandak) balaboeb ka Bandjarallah?’. Lihat J. Mallinckrodt, 1928, Het Adatrecht van Borneo, Deel I, Leiden: M. Dubbeldeman, hlm. 47. Ini menunjukkan bahwa menuju Banjar dengan menggunakan perahu, yang kemudian justru ketika jalan darat telah dibuat, istilah balabub (berangkat ke hilir sungai) tetap dibahasakan meskipun sudah menggunakan sepeda atau mobil. Berlabuh menuju Banjar menandakan konsep Banjar sebagai kota tujuan, sekaligus menjadi konsep bangsa. 
abad ke-18 hingga abad ke-19 terstruktur dalam birokrasi Kesultanan (Top Down), dengan adanya Mabkamah Syariah dan Undang Undang Hukum Sultan Adam 1835, namun sekali-kali tidak menghambat hak-hak adat dan hukum adat komunitas Dayak Kaharingan dan Balian. Islamisasi terbentuk melalui proses jaringan sosial, yang saling bersinergi antara jaringan sosial karena emosional-Bububan, kepentingan, dan kuasa. Oleh sebab itu, Islamisasi Banjarmasin berlangsung secara damai (penetration pacifique).

Islamisasi Banjarmasin menghasilkan identitas baru pada etnis Dayak Islam sebagai Melayu sekaligus menjadi Banjar, ${ }^{79}$ dan demikian pula etnis lainnya seperti; Jawa, Melayu, Bugis-Makassar serta Wajo, khususnya mereka yang berafiliasi, bercampur dan berada dalam suzerinitas Kesultanan Banjar. Suku-suku bangsa ini menghasilkan generasi campuran (mixing generation) karena perkawinan, yang juga menjadi Banjar. Berbagai etnis ini disatukan oleh transformasi dan transkulturasi religiusitas secara genius dari kepercayaan dan budaya Kaharingan-Balian, Hindu-Budha kepada agama Islam dan menjadi berbudaya Islam. Mereka memiliki bahasa Melayu Banjar sebagai Lingua-Franca, sekaligus sebagai bahasa pemersatu. Mereka memiliki sebuah Negara Bangsa (Nation State) yang bernama Kesultanan Banjar. Karena itu, sebutan Banjar pada mulanya merupakan identitas kebangsaan, identitas tanah banyu, dan identitas kebahasaan, serta identitas keagamaan, meskipun yang terakhir ini diekspose secara politis oleh Belanda, untuk memisahkan antara sebagian besar Dayak yang menjadi Banjar karena Islam, dengan sebagian Dayak yang masih beragama Kaharingan-Balian atau yang menjadi Kristen. Kenyataannya Banjar dan Dayak tetap merasa "Badangsanak" sampai sekarang. Inilah realitas

\footnotetext{
${ }^{79}$ Kenyataan ini ditandai dengan alur cerita dan kemiripan Naskah-Naskah Hikayat yang dianggap bercorak Melayu, sehingga Hikayat Banjar dan Tutur Candi, memiliki genre yang senada dengan Hikayat Hang Tuah, Hikayat Raja Pasai, Sulalat al-Salatin (Sejarah Melayu), Hikayat Aceh, Cerita Asal Bangsa Jin dan Segala Dewa-Dewa, Salasilab Kutai, yang semuanya menampilkan aspek bahasa Melayu; bahasa sastra, politik dan hukum serta bahasa komunikasi. Lihat Henri Chambert-Loir, 2011, Sultan, Pablawan dan Hakim, KPG (Kepustakaan Populer Gramedia) bekerjasama dengan Ecole francaise d'Extreme-Orient Masyarakat Pernaskahan Nusantara Pusat Pengkajian Islam dan Masyarakat-UIN Jakarta: Jakarta, hlm. 7. Hasil Penelitian antropologis Y. C. Thambun Anyang, menunjukkan bahwa komunitas Dayak Taman di Kalimantan Barat ketika telah Islam menyebut dirinya "turun Melayu" atau 'menjadi Melayu". Lihat Y. C. Thambun Anyang, 1998, Kebudayaan dan Perubahan Daya Taman Kalimantan Dalam Arus Modernisasi, Studi Etnografis Organisasi sosial dan Kekerabatan dengan Pendekatan Antropologi Hukum, Jakarta: Grasendo, hlm. 103. Bandingkan dengan proses diakronis sejak abad ke-15 dalam perspektif Dayak Islam di Banjarmasin yang menjadi Melayu dan juga menyebut dirinya Banjar, sering disebut pula Melayu Banjar.
} 
historis terbentuknya bangsa Banjar dalam sebuah bingkai kedaulatan Negara Bangsa yang disebut Kesultanan Banjar, sebagai buah dari Islamisasi Banjarmasin sejak abad ke-15.

\section{Daftar Pustaka}

\section{Arsip, Buku, Jurnal Ilmiah, Tulisan Ilmiah}

Abdurrahman, 1992, Menguak Sisi-Sisi Gelap Proses Perkembangan Islam di Kalimantan Selatan, Makalah dalam Seminra Sejarah Program Studi Pendidikan Sejarah FKIP UNLAM, Banjarmasin.

Abdurrahman, 1999, Upaya Menyingkap Misteri Datu Sanggul Tokoh Legendaris atau Tokoh Sejarah, Makalah, disampaikan pada acara bedah buku Biografi Datu Sanggul, Rantau: 25 November 1999.

Abu Daudi, 1996, Maulana Syekh Mubammad Arsyad Al-Banjari, Martapura: Sekretariat madrasah 'Sullamul Ulum' Dalam Pagar,

Abu Daudi, 2003,Maulana Syekh Muhammad Arsyad Al-Banjary (Tuan Haji Besar), Martapura: Yayasan Dalam Pagar (YAPIDA).

A.B. Lapian, 2008, Pelayaran dan Perniagaan Nusantara Abad ke-16 dan 17, Jakarta: Komunitas Bambu.

Hasjmy, Adakah Kerajaan Islam Perlak Negara Islam Pertama di Asia Tenggara, dalam A. Hasjmy, 1981, Sejarah Masuk dan Berkembangnya Islam di Indonesia, (Kumpulan Prasaran Pada Seminar di Aceh), PT. AlMa'arif.

Ahmad Gazali Usman, 1999, Riwayat Datu Sanggul dan Para Datu-Datu, Rantau: Pemerintah Kabupaten Dati II Tapin.

Ahmad Gazali Usman, 1989, Orang Banjar Dalam Sejarah, Diktat, Program Studi Pendidikan Sejarah FKIP UNLAM.

Ahmad Gazali Usman, 2000, Tradisi Baayn Maulud 12 Rabiul Awal Di Mesjid Keramat Banua Halat Rantau-Kabupaten Tapin, Rantau: Pemerintah Kabupaten Daerah Tingkat II Tapin.

Kardiyat Wiraharyanto, 2008, Sejarah Indonesia Madya Abad XVI-XIX, Yogyakarta:Universitas Sanata Dharma.

Alfani Daud, 1997, Islam dan Masyarakat Banjar: Deskripsi dan Analisis Kebudayaan Banjar. Jakarta:Penerbit PT. Raja Grafindo Persada. 
Alwi Shihab, 2009, Antara Tasawnf Sunni \& Tasawnf Falsafi, Akar Tasawuf di Indonesia, Jakarta: Pustaka Iman.

Aminuddin Kasdi, Kepurbakalaan (Sunan Giri Sosok Akulturasi Kebudayaan Jawa Hindu dan Islam Pada Abad 15-16), IAIN Surabaya, 1987.

Amir Hasan Bondan, 1953, Sulub Sedjarah Bandjarmasin, Pertjetakan Fadjar.

Azyumardi Azra,2002, Islam Nusantara, Jaringan Global dan Lokal, Bandung: Mizan.

Bambang Rudito. Melia Famiola. 2008. Social Mapping Metode Pemetaan Sosial Tehnik. Memahami Suatu Masyarakat atau Komuniti. Penerbit Rekayasa Sains. Bandung.

Bambang Subiyakto dan Djoko Suryo, 2001, Pelayaran Sungai di Kalimantan Tenggara: Tinjauan Historis tentang Traansportasi Air Abad XIX, Sosiohumanika, Vol. 14 No. 1 Januari 2001, Yogyakarta: Program Pasca Sarjana UGM.

Beeckman, Daniel, 1718, A Voyage to and from the Islands of Borneo in the East Indies, London. Dicetak kembali di London, Dawsons, 1973.

Burger, D.H., 1983, Sejarah Ekonomi Indonesia dari Segi Sosiologi Sampai Akhir Abad XIX, disusun kembali oleh Prajudi Atmosudirdjo, Jakarta: Pradnya Paramita.

Chairunnisa, 2003, Penokohan Syekh Abdul Hamid Abulung Sebagai Penyebar Ajaran Wabdatul Wujud di Kalimantan Selatan Pada Awal Abad XVIII dan Pada Awal Abad XIX, Skripsi: Banjarmasin, Program Studi Pendidikan Sejarah Jurusan Pendidikan IPS FKIP UNLAM.

Chambert-Loir, Henri. 2011, Sultan, Pablawan dan Hakim, KPG (Kepustakaan Populer Gramedia) bekerjasama dengan Ecole francaise d'ExtremeOrient Masyarakat Pernaskahan Nusantara Pusat Pengkajian Islam dan Masyarakat-UIN Jakarta: Jakarta.

Chaudhuri, K.N., 1989, Trade And Civilization in The Indian Ocean An Economic History From The Rise of Islam to 1750, Cambridge: Cambridge University Press, dalam M. Dien Majid, 2008, Berbaji Di Masa Kolonial, Jakarta: CV. Sejahtera. 
Clereq, FSA. de, 1877, De Vroegste Gescheidenis van Bandjarmasin, dalam Tijdschrift voor Indisch Taal-Volken kunde, XXIV.

Colenbrander, H.T., 1925, Koloniale Gescheidenis II, Den Haag.

Diah Ratna Wulan, 2008, Komunitas Bakumpai Di Buntok (Barito Selatan) Dari Abad Ke-15 Hingga Dasawarsa Pertama Abad Ke-21, Skripsi, Banjarmasin: Program Studi Pendidikan Sejarah Jurusan P.IPS FKIP UNLAM.

Dijk, L.C. van, 1862, Het Neerlands vroegste betrekkingen met Borneo; Solo-Archipel, Cambodja, Siam en Cocbin - China.Encyclopeidie Nederlands Indie, I.

Fahrurraji Asmuni, 2002, Cerita Datu-Datu Terkenal Kalimantan Selatan, Kandangan: Toko Buku \& Penerbit Sahabat.

Goh Yoon Fong, 1969, Trade and Politics in Banjarmasin 1700-1747, Thesis, London.

Groneveldt, W.P., Nusantara Dalam Catatan Tionghoa, Jakarta: Komunitas Bambu.

Gunadi Kasnowihardjo, et.al, 2006, Kajian Reka Ulang Replika Keraton Banjar di Kuin, Dinas Kebudayaan dan Pariwisata pemerintah Propinsi Kalimantan Selatan.

Hageman, J., Bijdrage tot de gescheidenis van Borneo,TBG, 1857.

Hasan Muarif Ambary, 1996, Dinamika Sejarah dan Sosialisasi Islam di Asia Tenggara Abad 11M-17M, dalam Kongres Nasional Sejarah 1996 sub tema Studi Komparatif dan Dinamika Regional, 1996, Jakarta: Departemen Pendidikan dan Kebudayaan RI.

Helius Syamsuddin, 2001, Pegustian dan Tumenggung, Akar Sosial, Politik, Etnis, dan Dinasti Perlawanan di Kalimantan Selatan dan Tengah 1859-1906, Jakarta: Balai Pustaka.

Herry Porda Nugroho Putro. 2009. Sungai di Kalimantan Selatan Dalam Perspektif Sejarah. Makalah pada Seminar Nasional Pendidikan "Kemaritiman Dalam Perspektif Historis dan Pendidikan". FKIP Unlam. Banjarmasin. 10 November 2009.

H. Muhammad Marwan, 2010, Manakib Datu Suban, Kandangan: Tim Sahabat. 
Husni Abar, 2003, Panembahan Muda Aling (Datu Muning) Sebuab Studi Kasus tentang Kekuasaan dalam Masyarakat Banjar, Rantau: Pemerintah Kabupaten Tapin Kalimantan Selatan.

H.W. Muhammad Shaghir Abdullah, 1992, Syekh Muhammad Arsyad Al-Banjary, Matahari Islam, Pondok Al-Fathanah.

Irawan Djoko Nugroho, 2011, Majapabit Peradaban Maritim Ketika Nusantara Menjadi Pengendali Pelabuban Dunia, Jakarta: Suluh Nuswantara Bakti.

Ismadi Dahri, 1991, Asal-Usul Kampung Marampiau. Makalah.

Jumiarti, 2003, Keberadaan Muara Rampiau di Kalimantan Bagian Tenggara Sebagai Bandar Perdagangan Pada Abad XIV Sampai Akbir Abad ke XV, Skripsi, Program Studi Pendidikan Sejarah Jurusan P.IPS FKIP UNLAM, Banjarmasin.

Kedushin, Charles, 2004. Introduction to Social Network Theory. Basic Network Concepts.

Lombard, Denys, 2005, Nusa Jawa : Silang Budaya Kajian Sejarah Terpadu Bagian I : Batas-Batas Pembaratan, diterjemahkan Winarsih Partaningrat Arifin, et.al, Jakarta: Gramedia Pustaka Utama.

Penerjemah Winarsih Partaningrat Arifin, et.al, Jakarta: Gramedia Pustaka Utama.

Maharsi Resi, 2010, Islam Melayu VS Islam Jawa, Menelusuri Jejak Karya Sastra Sejarah Nusantara, Yogyakarta: Pustaka Pelajar.

Mallinckrodt, 1925, Kolonial Tijddschrift.

Mallinckrodt, J., 1928, Het Adatrecht van Borneo, Deel I, Leiden: M. Dubbeldeman.

Manguin, Y.P., dan Nurhadi, 1987, Perahu Karam di Situs Bukit Jaras, Propinsi Riau. Sebuah Laporan Sementara, dalam A.B. Lapian, 1997, Dunia Maritim Asia Tenggara, dalam Sejarah Indonesia Penilaian Kembali Karya Utama Sejarwan Asing, Depok-Jakarta: Pusat Penelitian Kemasyarakatan dan Budaya Lembaga Penelitian Universitas Indonesia.

M. Asywadie Syukur, 2009, Pemikiran-Pemikiran Syekh Mubammad Arsyad AlBanjary Dalam Bidang Taubid dan Tasawuf, Banjarmasin: Center For Community Development Studies (COMDES) Kalimantan. 
Marko Mahin, 2004, Urang Banjar: Identitas dan Etnisitas di Kalimantan Selatan, Jurnal Kebudayaan Kandil, Edisi 6, Tahun II, Agustus-Oktober, Lembaga kajian Ke-Islaman dan Kemasyarakatan, Banjarmasin

Marwati Djoned Poesponegoro, Nugroho Notosusanto, 1984, Sejarah Nasional Indonesia Jilid III, Jakarta: PN. Balai Pustaka.

Meijer, J.J., 1949, Blanken of Borneo. Herinneringen van J.J. Meijer. Naverteld en van een inleiding voorzien door G.L. Tichelman. Amsterdam: A.J.G. Stenghold.

Meilink-Roelofsz, M.A.P., 1962, Asian Trade and European influence in the Indonesian archipelago between 1500 and about 1630, Den Haag, Martinus Nijhoff, dalam A.B. Lapian, 1997, Dunia Maritim Asia Tenggara, dalam Sejarah Indonesia Penilaian Kembali Karya Utama Sejarwan Asing, Depok-Jakarta: Pusat Penelitian Kemasyarakatan dan Budaya Lembaga Penelitian Universitas Indonesia.

Meyer, Indische Gids 1899, I,

M. Idwar Saleh, 1962, Sedjarah Bandjarmasin, Bandung: Balai Pendidikan Guru.

M. Idwar Saleh, 1980-1981, Rumah Tradisional Banjar Rumah Bubungan Tinggi, Banjarbaru: Museum Negeri Lambung Mangkurat Propinsi Kalimantan Selatan.

M. Idwar Saleh, 1983/1984, Sekilas Mengenai Daerah Banjar dan Kebudayaan Sungainya Sampai Dengan Akbir Abad - 19, Banjarbaru: Museum Negeri Lambung Mangkurat Propinsi Kalimantan Selatan.

M. Idwar Saleh, 1986, Banjarmasih, Banjarmasin: Museum Negeri Lambung Mangkurat,

Miller, George, 1960, Plans and The Structure of Behavior, New York: Reinhart and Winston.

M. Laily Mansur, 1982, Kitab Ad-Durun Nafis Tinjauan Atas Suatu Ajaran Tasawnf, Banjarmasin: Hasanu.

Muhammad Syamsu As, 1999, Ulama Pembawa Islam di Indonesia dan Sekitarnya, Jakarta: Lentera.

M. Suriansyah Ideham, et.al, 2005, Urang Banjar dan Kebudayaannya, Banjarmasin: Badan Penelitian dan Pengembangan Daerah Pemerintah Propinsi Kalimantan Selatan. 
Mu'jizah, 2009, Iluminasi dalam Surat-Surat Melayu Abad ke-18 dan ke-19, Surat No.41, KPG.

Mussellein, Bïdragen K 1, 1888.

MZ. Arifin Anis. 2000. Banjarmasih Sebagai Bandar Perdagangan Pada Abad XVII. Vidya Karya, Jurnal Pendidikan dan Kebudayaan FKIP UNLAM. Banjarmasin. Tahun XVIII, No.2, Oktober 2000.

M.Zurkani Yahya, Bahasa Banjar Arkais Dalam Kitab Sabilal Mubtadin, Makalah, Disampaikan pada Diskusi Panel Bahasa Banjar Tanggal 24 Oktober 1992, Banjarmasin: Kelompok Studi Masyarakat dan Budaya Pusat Penelitian Universitas Lambung Mangkurat.

Naskah Syair Huwal-Awwal Damai Dandam ditemukan di kampung Tambak Anyar, Martapura.

Oemar Zainuddin, 2010, Kota Gresik 1896-1916, Sejarah Sosial Budaya dan Ekonomi, Jakarta: Ruas.

Rahmadi, 2010, Jaringan Intelektual Ulama Banjar Abad XIX dan XX (Studi Tentang Proses, Pola dan Ekspansi Jaringan), Banjarmasin: Antasari Press.

Ramli Nawawi, 1980/1981, Sejarah Pendidikan di Kalimantan Selatan, Banjarmasin: Departemen Pendidikan dan Kebudayaan Kalimantan Selatan.

Ras, J.J. Hikayat Banjar, The Malay Mythe of Origin, The Hague: Martinus Nijhoff.

Reid, Anthony, 1992, Asia Tenggara Dalam Kurun Niaga 1450-1680, Jilid I : Tanah di Bawah Angin, Penerjemah Mochtar Pabottinggi, Jakarta: Yayasan Obor Indonesia.

Ricklefs, M.C., 1993, Sejarah Indonesia Modern, Jogyakarta: Gadjah Mada University Press.

Ridin Sofwan, et.al, 2004, Islamisasi di Jawa, Wali Songo, Penyebar Islam di Jawa Menurut Penelitian Babad, Yogyakarta, Pustaka Pelajar.

Rijfer, G.F., tt, Beberapa Studi Tentang Sejarah Islam di Indonesia 1900-1950, Penerjemah Tudjimah dan Yessy Augusdin, Jakarta: Bulan Bintang.

Ruddy Agusyanto. 2009. Jaringan Sosial Dalam Organisasi. Jakarta: Penerbit Rajawali Pers.

Sartono Kartodirdjo, 1987. Pengantar Sejarah Indonesia Baru: 1500-1900, Dari Emporium Sampai Imperium, Jilid I, Jakarta: Penerbit PT Gramedia.

Schriecks, B. Indonesian Sociological Studies, Bab II, Ruler and Realm in Early Java. 
Schwaner, dalam Helius Syamsuddin, Pegustian dan Temenggung, Akar Sosial, Politik, Etnis, dan Dinasti . Perlawanan di Kalimantan Selatan dan Kalimantan Tengah 1859-1906, Jakarta : Balai Pustaka.

Siti Chamamah Soeratno, 1997, Hikayat dan Syair "Penyimpan "Data Sejarah, Suatu Tinjauan Susastra, dalam Sejarah Indonesia Penilaian Kembali Karya Utama Sejarawan Asing, Depok-Jakarta: Pusat Penelitian Kemasyarakatan dan Budaya Lembaga Penelitian Universitas Indonesia.

Slamet Muljana, 2006, Sriwijaya, Yogyakarta: LKis.

Suarez,Thomas. 1999, Early Mapping of Souteast Asia "The Epic Story of Seafarers, Adventurers, and Cartographers, Who First Mapped The Regions between China and India", Singapore-Hongkong-Indonesia: Periplus Editions.

Surat-surat Perjanjian antara Kesultanan Bandjarmasin dengan Pemerintaban V.O.C. Bataafse Republik, Inggeris dan Hindia-Belanda 1635-1860: Jakarta, Arsip Nasional Republik Indonesia Kompartimen Perhubungan Dengan Rakyat.

Syaiful Arif, 2010, Refilosofi Kebudayaan Pergeseran Pascastruktural, Jogjakarta: ArRuzz-Media.

Tan Ta Sen, 2010, Cheng-Ho Penyebar Islam dari China ke Nusantara, Jakarta: Kompas.

Taufik Abdullah et.al, Tesis Weber dan Islam di Indonesia, dalam Agama, Etos Kerja dan Perkembangan Ekonomi, Jakarta: LP3ES.

Tim Alih Tulisan, 2001, Inilah Kitab Yang Dinamakan Dia Durrun Nafis (Mutiara Yang Indah) Pada Menjelaskan Wabdatul Af'al, Asma dan Zat-Zat Taqdis, Tabalong: Kerjasama Komunikasi dan Silaturrahmi Keluarga Alumni PMII Kabupaten Tabalong dengan Pemerintah Kabupaten Tabalong.

Tim Depdikbud, 1987/1988, Kesenian Rakyat Kalimantan Selatan Lamut', Banjarmasin: Dedikbud.

Tim Peneliti, 2000, Umur Candi Laras Dalam Panggung Sejarah Indonesia Kuno, Banjarbaru, Balai Arkeologi.

Tim Sahabat, 2008, Cerita Datu-Datu Terkenal Kalimantan Selatan, Kandangan: Toko Buku dan Penerbit Sahabat.

Thorn, Mayor William, 2004, Penaklukan Pulau Jawa-Pulau Jawa di abad Sembilan belas dari amatan seorang serdadu Kerajaan Inggeris, penerjemah Noviatri, Jakarta: PT. Elex Media Komputendo. 
Tutung Nurdiyana, 2010. Superioritas Banjar Dalam Empat Mitos bubungan Banjar dan Dayak. (Mitos Kosmogini Datu Adam dan Datu Tihawa, Legenda Raksasa dari Langit, Matundang Kaling dan Legenda Kerajaan Kayu Tangi). Banjarmasin.

Uka Tjandrasasmita, 2009, Arkeologi Islam Nusantara, Jakarta: KPG (Kepustakaan Populer Gramedia) bekerjasama dengan Ecole francaise d'Extreme-Orient dan Fakultas Adab dan Humaniora UIN Syarif Hidayatullah.

Uka Tjandrasasmita "The Arrival and Expansion of Islam in Indonesia in Relation to Southeast Asia, dalam Mulyanto Sumardi (ed.), International Seminar on Islam in Southeast Asia, dalam Ahmad M. Sewang, 2005, Islamisasi Gowa (Abad XVI Sampai Abad XVII), Jakarta: Yayasan Obor Indonesia.

Valentijn, Francois, 1726, Beschrijving van het eiland Borneo, en onzen handel aldaar. Oud en Niew Oost Indien. III, Dordrech: van Bram.

Wertheim, W.F., dalam "Religious Reform Movements in South and South East Asia" (Gerakan Pembaharuan Agama di Asia Selatan dan Asia Tenggara), Archive de Sociologie des Relegions, No. 12, 1961, Paris.

Wolters, O.W., 2011, Kemaharajaan Sriwijaya dan Perniagaan Dunia Abad III-Abad VII, Jakarta:Komunitas Bambu.

Y. C. Thambun Anyang, 1998, Kebudayaan dan Perubaban Daya Taman Kalimantan Dalam Arus Modernisasi, Studi Etnografis Organisasi sosial dan Kekerabatan dengan Pendekatan Antropologi Hukum, Jakarta: Grasendo.

Yustan Aziddin, tt, Kesenian Tradisional Yang Berbubungan Dengan Kepercayaan Rakyat Daerah Kalimantan Selatan, Banjarmasin: Kanwil Depdikbud Propinsi Kalimantan Selatan.

Yustan Aziddin, etal, 1980/1981, Cerita Rakyat Daerah Kalimantan Selatan, Jakarta: Departemen Pendidikan dan Kebudayaan Proyek Inventarisasi dan Dokumentasi Kebudayaan Daerah.

\section{Artikel Surat Kabar}

Abdurrahman, "Mengenal Karya Tulis Ulama Banjar (Bagian IV), Menelusuri Karya Syekh Muhammad Arsyad Al-Banjari”, Dinamika Berita 21 November 1991.

K.H. Husein Nafarin, Datuk Kandang Haji, Banjarmasin Post, Banjarmasin: Jumat 14 Mei 2010, hlm. 1 
